\title{
Natural characterization of the low course of the Camaquã River in Cristal city-RS
}

\section{Caracterização natural do baixo curso do Rio Camaquã no município de Cristal-RS}

\author{
Elissandro Voigt Beier \\ Cristiano Poleto" \\ Maria Eugênia Moreira Costa FerreirallI
}

\begin{abstract}
A portion of the rural territory of the Cristal City-RS was analyzed in order to assess the natural characteristics such as pedology, geology, geomorphology, water network, climatology and the biogeography of this geographical area. For the survey, bibliographical sources such as topographic charts, survey maps of IBGE, reference sources like phytogeographic surveys, and detailed studies of sedimentary and hydrological dynamics that transformed the region in the past were considered. From this study, specific characteristics for each of the analysis categories were mapped in definite charts and analyzed in their context of occurrence. As a result, it was possible to characterizate the natural conditions of the region whose current scenario presents significant differentiation by the anthropic interference in the environment.
\end{abstract}

Keywords: Natural characterization; Watershed of Camaquã River; Phytogeographic landscape

\section{Resumo}

Analisou-se uma parcela do território rural do município de Cristal-RS, onde foram levantadas as características naturais como pedologia, geologia, geomorfologia, rede hídrica, climatologia e a biogeografia desta parcela geográfica. Para o levantamento foram consideradas fontes bibliográficas como cartas topográficas, mapas de levantamento do IBGE, fontes de referência como levantamentos fitogeográficos e estudos aprofundados de dinâmica sedimentar e hidrológica que trasnformaram a região no passado. Deste estudo foram levantadas características específicas para cada uma das categorias de análise sendo mapeadas em cartas específicas e analisadas em seu contexto de ocorrênica. Resultando em uma caracterização das condições naturais da região, cujo cenário atual, apresenta significativa diferenciação pela interferência antrópica no meio.

Palavras-chave: Caracterização natural; Bacia hidrográfica do Rio Camaquã; Paisagem fitogeográfica

'Doutorando em Geografia, Departamento de Geografia, Universidade Estadual de Maringá, Maringá, PR, Brasil.

"Doutor em Recursos Hídricos e Saneamento Ambiental, Departamento de Engenharia Ambiental, Universidade Federal do Rio Grande do Sul, Porto Alegre, RS, Brasil. cristiano.poleto@ufrgs.br

"'Doutora em Geografia, Departamento de Geografia, Universidade Estadual de Maringá, Maringá, PR, Brasil.

eugeniaguart@hotmail.com 


\section{Introduction}

The study area and its environmental characteristics such as geology were delimited: the pedology resulting from the decomposition of the rock, the geomorphology, the geography conditioned by the climate and the water resources that characterize these distinct spaces, besides the areas covered by the vegetation and that are the result of the interactions between the natural components, forming the environmental system of the region.

Cristal is a municipality located in the south of the Rio Grande do Sul State and it is considered small according to the classification of the Brazilian Institute of Geography and Statistics (IBGE, 2016). It has a territorial unit area of $681,625 \mathrm{~km}^{2}$, with an estimated population of 7,792 inhabitants, predominantly urban, although it is important to consider that the local economy is based on rural production.

The municipality is in the south of the Rio Grande do Sul State and it is located

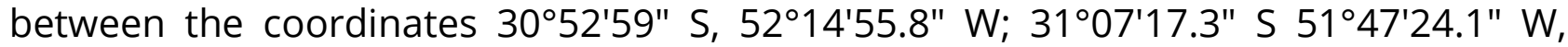
being fully inserted in the Camaquã river basin, specifically in the low river course.

The area has transitional environmental characteristics conditioned by geology, geomorphology and local geography, which resulted in a diversity and overlap of species of two different natural systems, to the east the internal lagoon plain, and to the west the southeastern mountain range, a region that requires the understanding of its particularities.

The study area presents approximately $36 \mathrm{~km} 2$ which is divided in two sets that present distinct characteristics and overlap in geological, geomorphological, pedological and biogeographic aspects and also in the use and occupation of the soil in the present day.

The research area is located in the northwest quadrant of Cristal City-RS and it is shown in Figure 01. The territory has as limits to the north, northeast and east the margin of the Camaquã River; to the south and southwest, the road from Sapata which connects the seat of the municipality of Cristal to the municipality of Canguçu and, as a delimiter in the west quadrant, there exists the rural road linking the 
interiority of Butiá to the municipality of Amaral Ferrador located on the left bank of the Camaquã River.

The entire research area is in a rural, agricultural and intense mechanized context, with a differentiation of the division and occupation of the soil conditioned by the immigration process and the different natural conditions of the region.

The Northwest sub-region of the research area corresponds to the steepest area, with granite outcrops and small farms occupied by late European immigration; and a second area in the SE quadrant where there are large rural properties with a lower degree of slope, with almost no existence of rocky outcrops. The latter, it was the product of the appropriation of allottees and descendants of Spaniards and Portuguese in the first movements of Europeans in the region and, due to the natural characteristics, propitiated the agriculture of large scale and fields of extensive creation.

The soil use through agricultural practices such as intensive mechanization and other practices that require direct interference such as earth-moving processes, largescale removal and inversion of soil, and road construction are some of the major processes that cause deterioration and loss of the archaeological and cultural heritage in the region of study, as identified during the bibliographic reference.

Human activities, in general, alter and interfere in the stratigraphy of the sites or in environments with the presence of cultural patrimony (HOFMAN, 1986; KELLY, 1992).

For the area composed of small rural properties, which covers the region of the edge of the Southeast, a great concentration of archaeological sites was identified; the second region differentiated by land occupation, with large rural properties, presents a lower density of archaeological sites identified (SOCIOECONOMIC ATLAS, 2002).

For the area composed of small rural properties which covers the region of the edge of the Southeast mountain range, a great concentration of archaeological sites was identified; the second region differentiated by land occupation, with large rural properties, presents a lower density of archaeological sites identified (SOCIOECONOMIC ATLAS, 2002). 
Figure 01- Representation of the study area

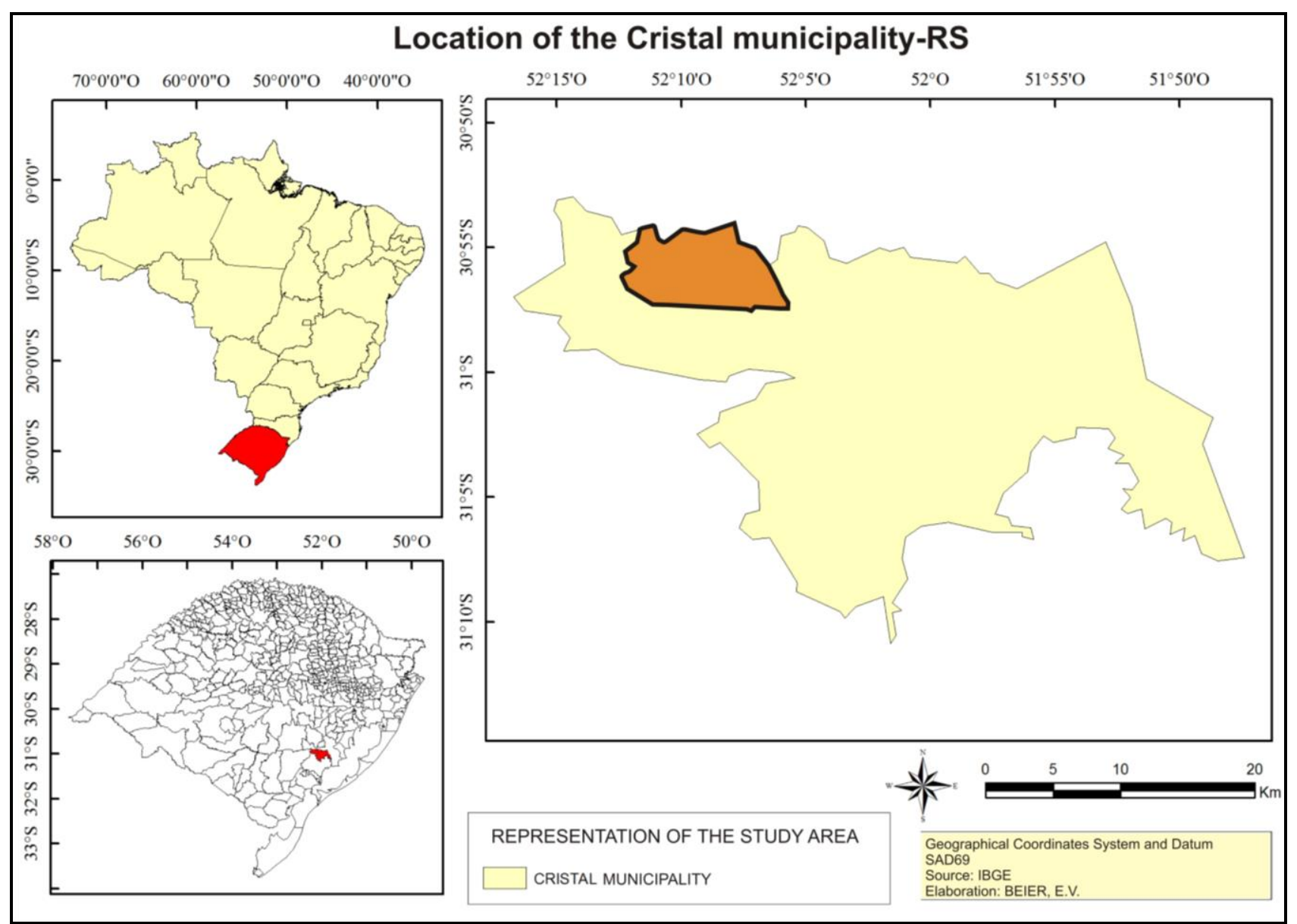

Source: BEIER, 2017

\section{Environmental Characterizations of the Lower Valley of the Camaquã River}

Some natural features that shape and interfere with the landscape have been considered. These characteristics have modified the environment over geological time and, observing the area, it is easier to discuss these characteristics through the morphology of geographic space and the appropriation of the same by the man from the past to the present.

\subsection{Geology}

Like the pedoturbation discussed earlier, the components of the site, artifacts or products produced by human intervention in the course of an occupation are analyzed here from a theoretical point of view. 
The rocks used by the paleoindigenous people in the manufacture of instruments are almost always available in outcrops, products of mechanical weathering and river transport, having being transported from distant original areas and deposited along the course of the river.

These outcrops are expressed by deposits of rolled pebbles, forming marginal banks with sand deposits (beaches) or exclusive (banks of pebbles) which, for this reason, form privileged sources of raw material (PROUS, 1986; 1990).

This phenomenon can be observed in the study area, considering that most of the lithic material identified in the sites comes from lithology external to the lithology of the study area. In doing so, it should be considered that the springs and the upper and middle portion of the course of the Camaquã River are located in a geological region distinct from the area of the low course where the study area is located.

The portion of the upstream territory is partially inserted into the sedimentary basin of the Camaquã River, which presents different volcano-sedimentary associations representative of the transition stage of the South American Platform (ALMEIDA, 1969, apud PEREIRA, 2011, p.24).

These sedimentary lithologies provide coarse sediments when affected by mechanical erosion, transporting them from the upper parts of the basin. Furthermore, rocks such as andesites, slate, quartzites, fine and coarse sandstones, conglomerates, argillites and rhythmites are identified in the upper course of the river (PEREIRA, 2011).

Within the geological contex, the área can be divided in two, having the Crystalline Shield or Crystal Basis to the north and the Internal Alluvial Plain composed by the quaternary sediments to the south and east, classifying the distinct spaces by their natural and anthropic characteristics.

The geology of the region is described in the Program of Basic Geological Surveys of the Brazilian Geological Service (SGB) in conjunction with the Company of Research of Mineral Resources (CPRM) and the area of interest of this study is 
installed predominantly on the Pre-Cambrian and Cambrian rocky massifs of the Dom Feliciano Orogenic Belt (ROISENBERG, 2007).

The shield is composed of rocks of varied ages from the Archaean to the Epochal. It presents associations of metamorphic rocks, igneous and sedimentary of diverse age, origin and evolution, distributed in a complex tecno-stratigraphic arrangement controlled by regional lineaments of predominant NE-SW and NW-SE orientations (ROISENBERG, 2007).

Characterizing the north-northeast portion, there exists the granite-gnassic basement represented by the Canguçu Complex (Figure 02) representing the preCambrian unit in the region. As examples of the Cambrian, it can be cited the granite suite Arroio dos Ladrões (ROISENBERG, 2007).

Bordering these lithologic units, there is the second part of the territory with varied sedimentary littoral from the Quaternary Tertiary age represented by the Guaxaim, Chuí formations and the estuary deposits (alluvial, lacustrine, eolic, marine, colluvial, present and subpresent) (ROISENBERG, 2007).

It comprises the internal alluvial plain or deltaic fluvial plain characterizing the adjacent sediments of the basement and deposited at its base, and the Pleistocene and Holocene lagoon deposits (Laguna Barreia System I, II, III and IV) dominated by deltaic fan systems (Fan Deltas), having as the main source rocks the lithology of the basement, and secondarily, the own deposits of this system, through cyclic reworking along the Quaternary, since its distal structures were reworked in a marine and later in a lagoon environment ( TOMAZELLI and VILLWOCK, 2000).

It is formed the alluvial fan systems located adjacent to uplands or water bodies, generating a complex of environments and sub environments (fluvial, paludal, lagoon, praial and marine) (BITENCOURT, 1992).

In doing so, it is considered the sea-level oscillations and the influence of marine transgressions and regressions for the region from the lower Pleistocene and Holocene (VILLWOCK et al., 1986).

It is contained in this latter formation of unconsolidated sediments such as alluvial, sands, gravel and silty-clayey of flood plains deposits. 
According to Bitencourt (1992, p.35):

Throughout the coastal plain, alluvial fan systems are generated from upland slopes, initially by gravitational mass movements, gradually moving to alluvial systems characterizing easy eluvial and colluvial, midslope regions, and easy alluvial regions in the lower regions. Conglomerates, diamictites, sandstones and argillites constitute the lithologies of the region.

Villwock and Tomazelli (1995) describe the formation of the coastal plain for the region as formed by alluviums, colluviums and alluvial fans developed the base of the slopes of the shield and Barrier I (Figure 03), including tertiary deposits in the valleys of the main water courses.

Alluvial Fan Depositional Systems are the result of dominantly gravitational processes such as the free fall of blocks, crawling and the flow of debris and that transverse, in the extreme portion, to sediments transported and deposited in aqueous media (alluviums) (TOMAZELLI and VILLWOCK, 2000).

Still, according to Tomazelli and Villwock (2000, p.40), "There is strong evidence that fluctuations between arid and moist climates that occurred in the Upper and Quaternary Tertiary had great influence on the development of this depositional system." Considering the climatic variations and the implications on precipitation rates and the development of the vegetation cover on the shield

Figure 02 - Geology representation for the study area

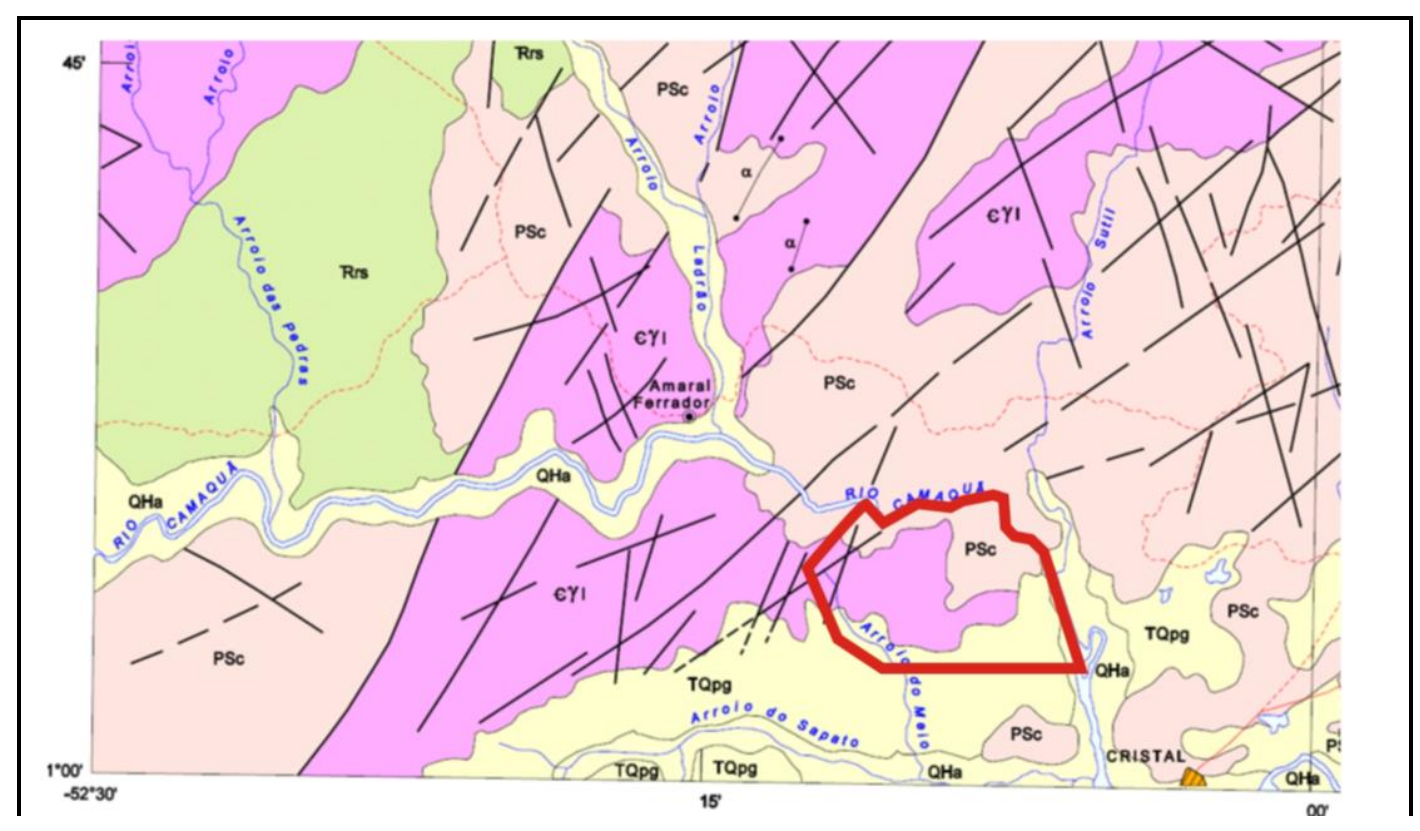




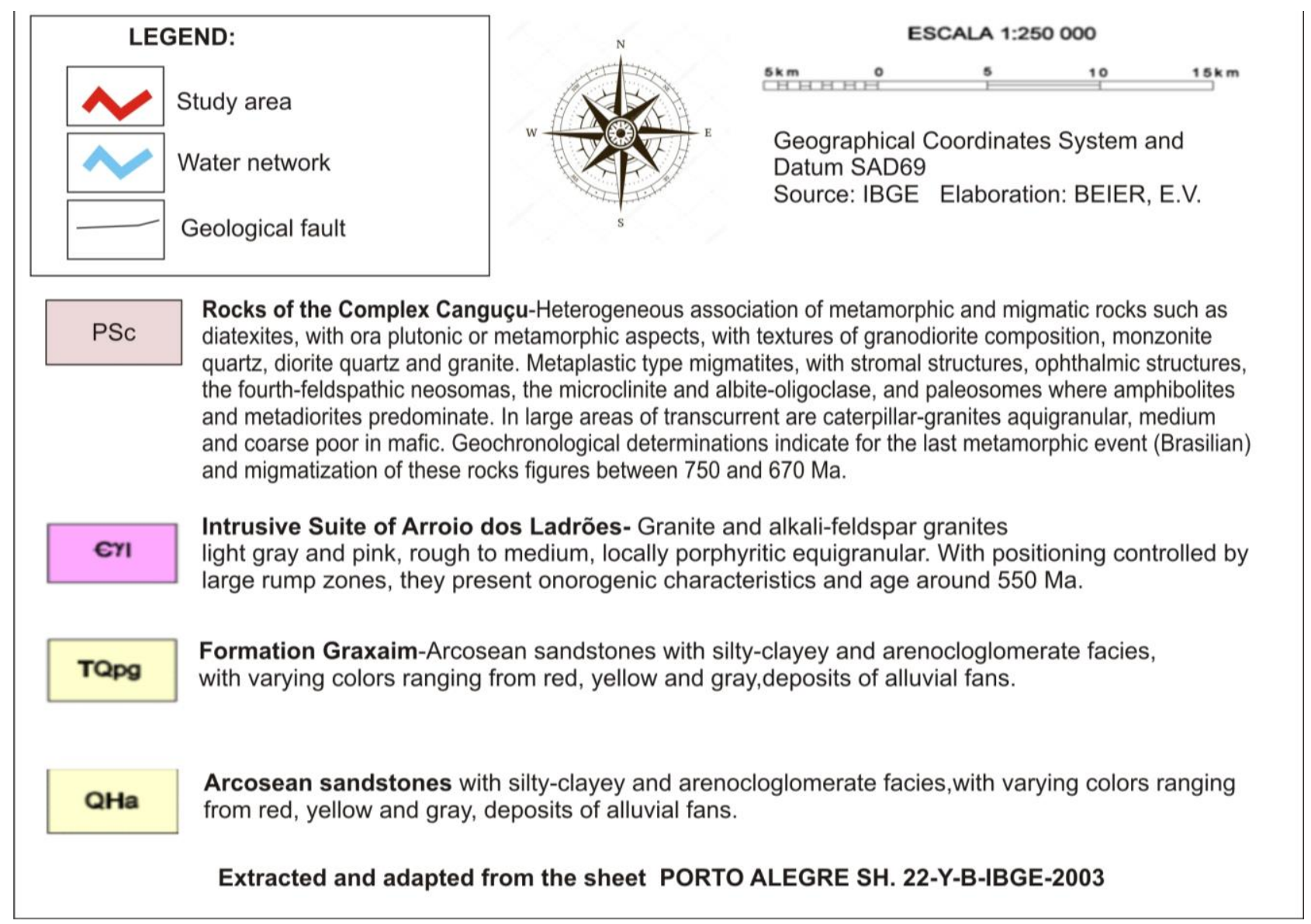

Source: Adapted from IBGE (2003)

\subsection{Geomorphology}

The study area presents varied geomorphological features considering the different lithologies, modeling processes and climatic conditions that occur over time.

According to Tomazelli and Villwock (2000, p.40), "Internal Alluvial Plain corresponds to the strip of land that extends between the highlands of the Sul-RioGrandense Shield and the large bodies of water of the Lagoon Patos-Mirim System." They are lands slightly sloped to the east where rounded coxillas of the borders of the shield give place to terraces dissected by the current drainage.

The crystalline shell or basement has a relief dissected by erosive agents, forming undulating slopes between the heights of $60 \mathrm{~m}$ and $90 \mathrm{~m}$, changing the landscape to strongly undulating slopes in heights higher than $90 \mathrm{~m}$, reaching a maximum dimension of $212 \mathrm{~m}$. 
According to Bittencourt (1992, p. 92), "In high regions, the slopes exhibit convex shapes, and in depressed regions (valleys or depressions) they exhibit concave forms where rocky blocks frequently appear."

Specifically, the study region is classified as being from the Canguçu-Caçapava Residual Plateau; Marginal low plateau, corresponding to a classified portion (NorthNorthwest portion), area with higher altitudes with a maximum topographic elevation of 212 meters of altitude and more pronounced slopes (STESA, 2010).

And a second portion identified as Internal Alluvial Plain; fluvial-deltaic plain (Eastern-Southeast portion), the morphological features that form part of this territory constitute the deltaic plains (swamps, lakes), fluvial channels (distributive channels, abandoned meanders), slightly sloping large fluvial terraces (marked by the edge of terraces) (BITENCOURT, 1992).

In this portion, the dimensions vary between a minimum of 19 meters and 60 meters approximately, where the relief presents smooth to wavy forms characterized by the small degree of inclination, with quite dissected slopes and notched by fluvio-delta systems implanted after its formation (BITENCOURT, 1992).

\subsection{Climatology}

The climate for the region is classified by Köppen (1936) as Cfa (temperate humid), subdivision of the general classification Cf (temperate climate), which results from regions with humid climate, when precipitation is well distributed in all months of the year without the existence of a defined dry season (as summarized in Table 01 and observed in Figure 04).

According to Köppen-Geiger (2007, p.01), "The classification is based on the assumption, originating from phytosociology and ecology, that the natural vegetation of each major region of the Earth is essentially an expression of the prevailing climate." 
Figure 03 - Representation of the portion of alluvial fans

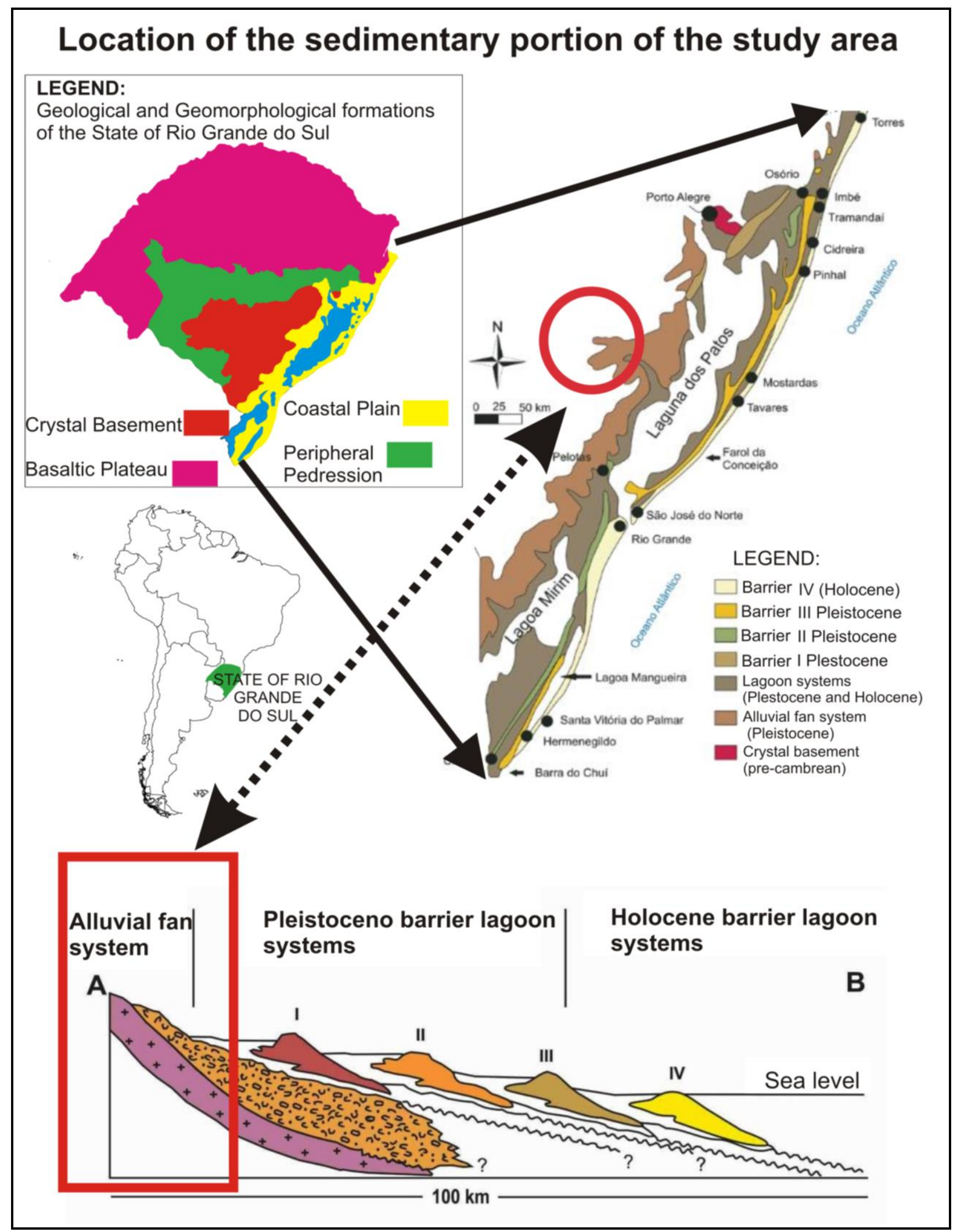

Source: Adapted from Tomazelli and Villwock, 2000 
Table 01 - Climatic classification for the study area

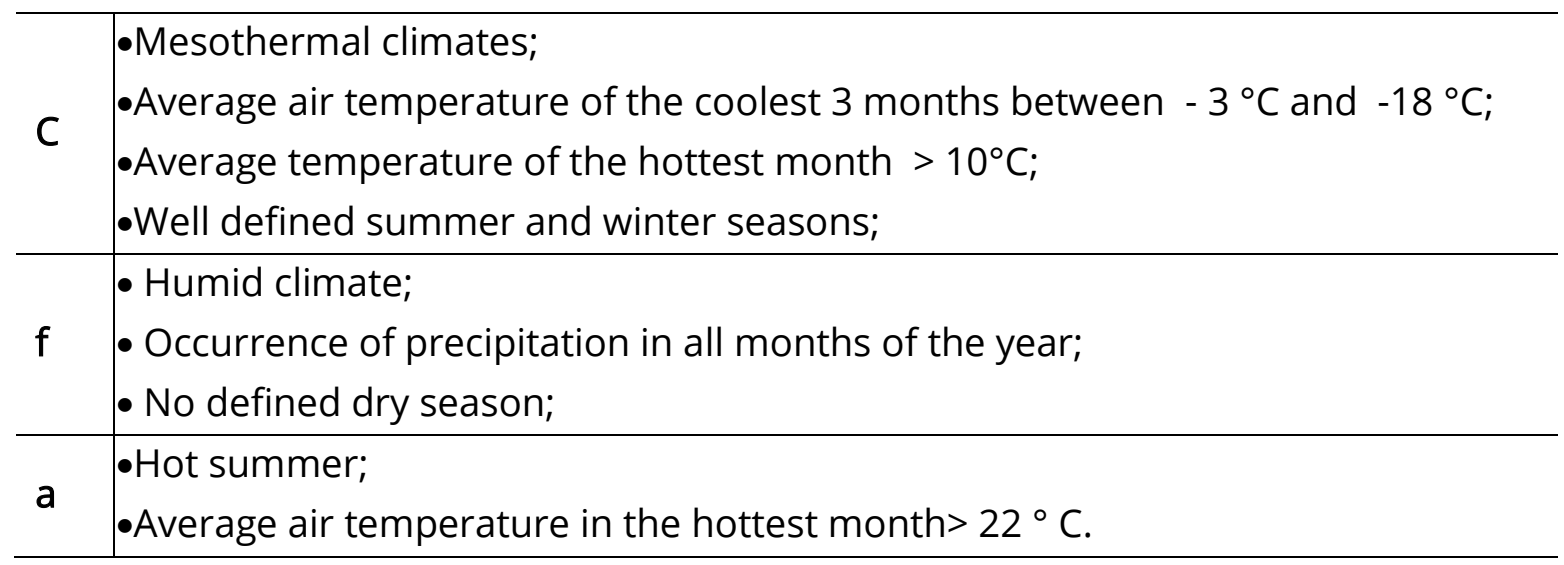

Source: Adapted from Köppen-Geiger (2007)

According to Rossato (2011), the average relative humidity of the air during the year for the region is concentrated in $79 \%$, not showing great variation in the different seasons of the year.

Furthermore, still as stated by Rossato (2011), rainfall averages do not show large oscillations during the year, with a history of concentrations of $400 \mathrm{~mm}$ in spring; 400 $\mathrm{mm}$ in summer; 350 in the fall and the maximum of $450 \mathrm{~mm}$ in winter, having a history of 1,600 mm / year.

Besides, it also occurs in the winter the lowest rates of solar radiation, considering the highest periods with clouds. They revolve around 80-100 days days with precipitation for the region, distributing 6-9 days on average for monthly precipitation. Average annual temperatures range from $17-20^{\circ} \mathrm{C}$. The study area presents higher values during the summer, specifically in the month of January with $20-26^{\circ}$ and in the month of July, during winter, the minimum averages of $11-14^{\circ} \mathrm{C}$ are presented (ROSSATO, 2011).

Winters are cold, with polar systems and less participation of tropical systems. In addition, the frontal systems are responsible for the highest rainfall concentrations throughout the year, considering the precipitation history for the winter.

The predominant atmospheric systems in the region correspond to the Antarctic Polar Mass (mPa), which is more active during the autumn and winter months, preferentially entering the south-southwest border, specifically along the border with 
Uruguay and Argentina, sometimes affected by rigorous winters due to the Pacific Polar Mass (mPp) with characteristics of dry and cold climate; At times, it has dry and hot characteristics with convective precipitation, being characterized by the incidence of hot North winds (mTc); Associated with the anticyclones of the South Atlantic, it acts with characteristics of hot conditions on a great part of the coast and the continent (mTa).

Figure 4 - Climatic classification for the study area

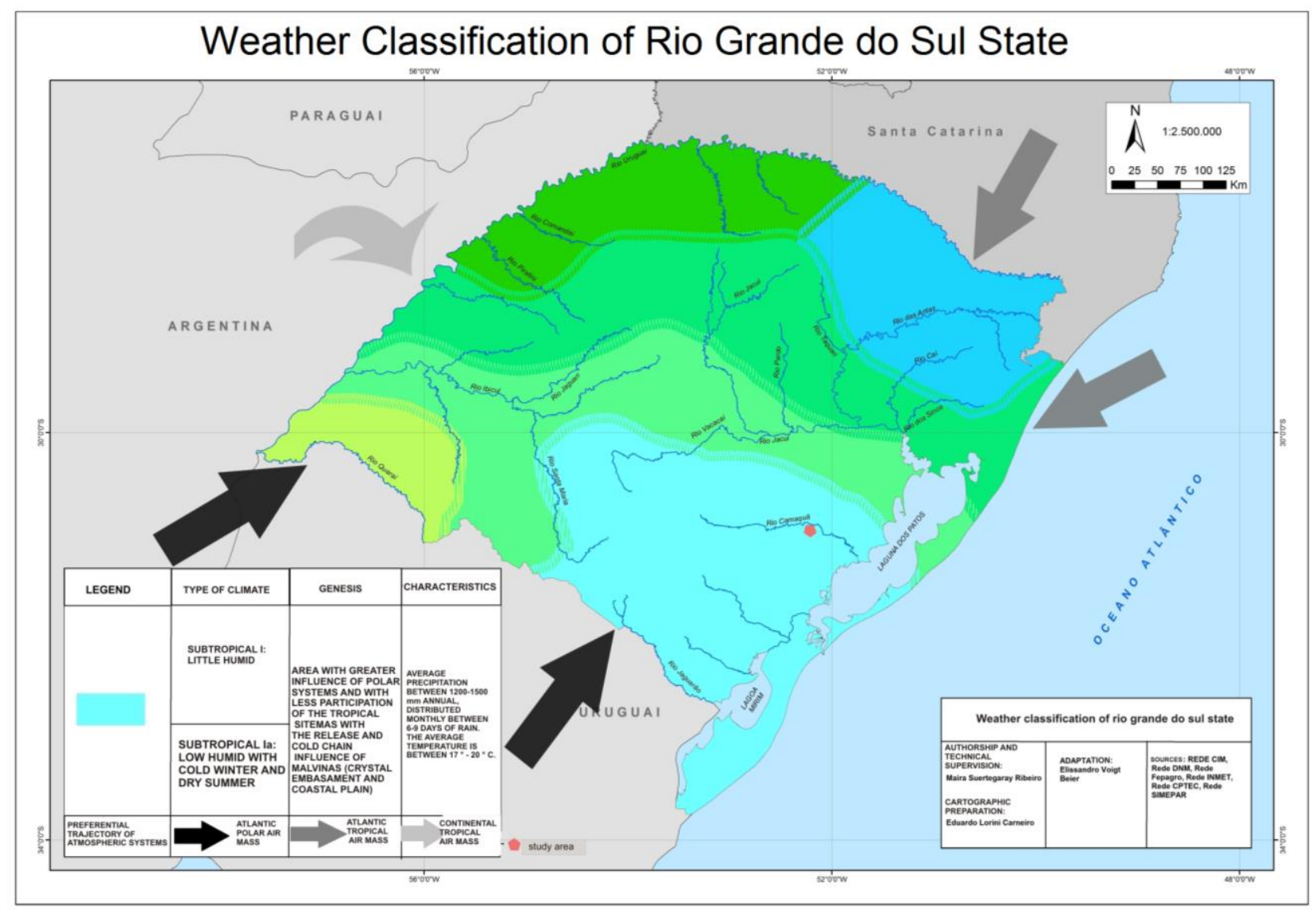

Source: Adapted from Rossato (2011)

\subsection{Pedology}

It is common for soils to derive directly from lithology and that the region has granite formation. The soils formed in this environment are not very thick in general, but are distinguished considering the topography and the relief, with a pedological formation in the topographic areas, with rocky outcrops and a differentiated pedological formation that results from the weathering of the source rock transported 
and deposited at low levels along the geological time, forming the quaternary alluvial fans, as shown in Figure 05.

The soils formed do not present very expressive profile, the mountainous region having a formation of horizons $\mathrm{A}$, being very quartz, well drained, clayey, little fertile naturally and with regolith with shallow depth.

According to IBGE (2003), there is a complex association of dystrophic lithographic soils with medium chalky texture; Cambisols dystrophic medium chalcky and clayey textures; Podzolic red-yellow dystrophic with medium / clayey texture; Podzolic Bruno grayish dystrophic and eutrophic medium / clayey texture with strong undulating relief and rock outcrops.

The less sloping region presents deeper, alluvial, colluvial and very clayey soils with a lower rate of quartz (BRAZIL, 1973).

According to IBGE (2003), for the organization of the region, it is proposed the classification of dystrophic Red-yellow Podzolic soil, argisol in which the base saturation is $50 \%$ with average low fertility.

They are characterized by medium-textured clayey sediments in wavy relief and average sandy texture in flat relief (IBGE, 2003).

In the region of alluvial fans are also found Planosol soils; Eutrophic Planosol and Eutrophic Gleysols. Because it represents the lowest part of the residual alluvial fan, it presents accumulation of excess water, with medium sand-clay texture and medium clay texture in the flat relief.

When its chemical composition is altered and it becomes acidic with a typical light color by the continuous location of water on it, it becomes less productive for many crops. Therefore, it used instead for grazing and eventual winter crops, being necessary the acidity correction of the soil (EMBRAPA, 1997).

From this differentiation of lithologys, results the variation of land uses and management for the region concentrating maize and tobacco in the upper and steepest part of the area and subsistence crops in small plots of the land, thus considering the outcrop of blocks of granite. 
On the other hand, in the flat region, the soil is uninterrupted due to lithological issues and the extensions of crops extend beyond the horizon. Therefore, the landscape is quite altered and even the smallest watercourses are renewed and altered with rectifications for its maximum exploitation in what concerns the expansion of soybeans, maize and, mainly, irrigated areas for rice-growing.

Figure 05 - Pedological classification for the region

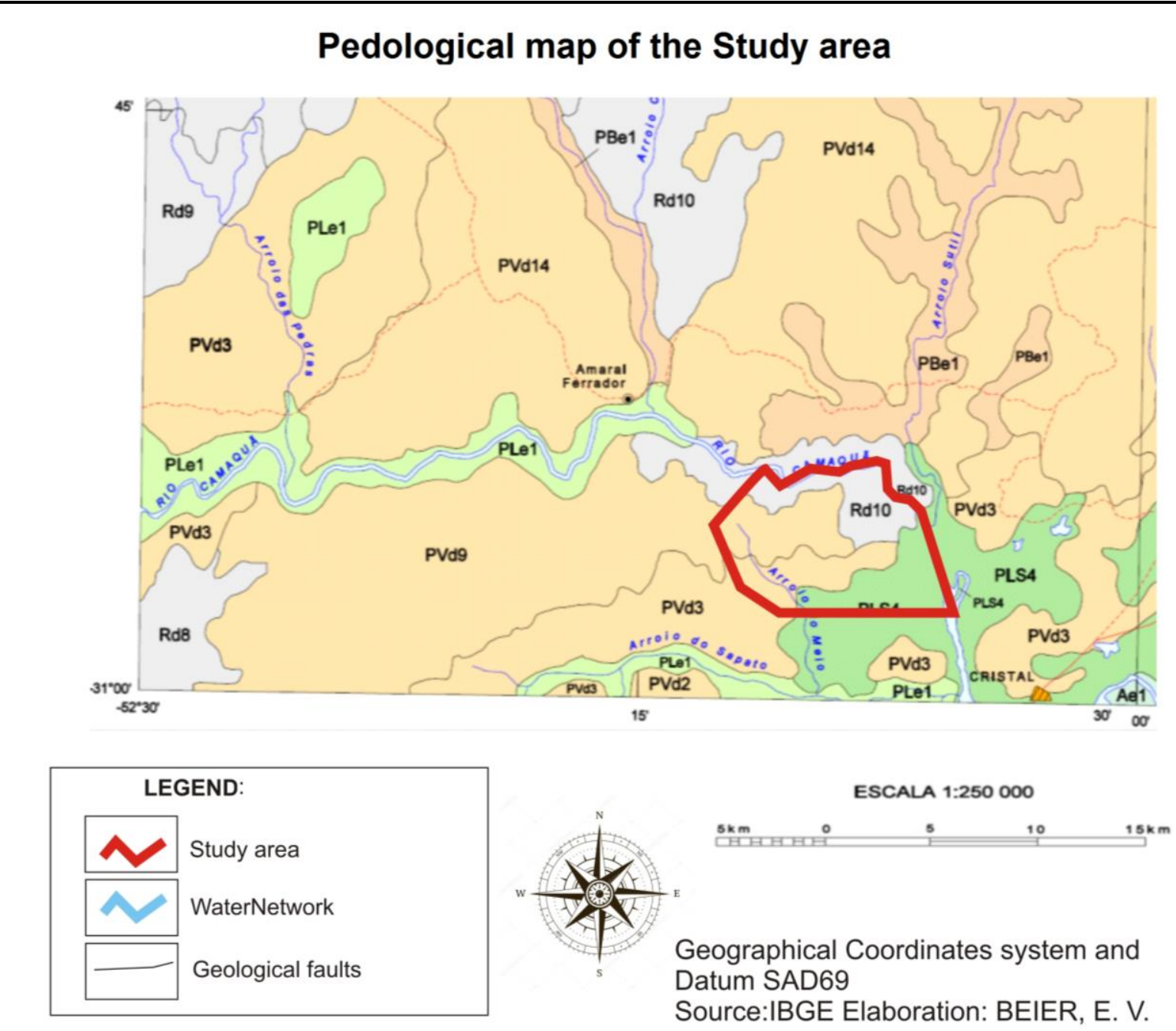

PVd

Podzlic soil red-yellow dystrofic

Pvd3-Podzolic red-yellow dystrophic Tb plinthic A moderate texture medium/clayey smooth relief wavy and eutrophic Planossol Ta A moderate sandy texture/medium flat relief.

PVd9-Podzolic Red-Yellow Dystrophic and Alico Tb Outstanding average gravel texture/clay gravel and medium gravel/clay

Podzólico Bruno-Dystrophic Gray Tb A Moderate medium texture of gravel/clayey soils and Litolics dystrophic A prominent medium texture gravel substrate migmatite relief smooth and wavy. 


\section{Rd10 Lithocyclic Dystrophic Soils}

Rd10-Complex association of dystrophic lithographic soils A moderate and prominent medium texture gravel substrate migmatite with Cambisols Tb A moderate and prominent medium texture gravel and clayey, chalky-red, Podzolic Red-yellow dystrophic Tb chalky A moderate texture medium/clayey, podzolic Bruno-grayish dystrophic and eutrophic Tb chalky A moderate texture medium/clayey strong relief and rock Outcrops.

PLS4

Planosol Solodico

PLS4-Planosol Solodic Ta A moderate sandy/medium and medium/clayey texture, Eutrophic Planosol A moderate to sandy texture/medium and medium/clayey and Gleisoil eutrophic Ta A moderate texture medium and clayey relief flat.

Extracted and adapted from the sheet PORTO ALEGRE SH. 22-Y-B-IBGE-PEDOLOGIC-2003

Source: Adapted from IBGE (2003)

\subsection{Water resources}

River drainage is composed of a set of interrelated flow channels that form the drainage basin, or river basin, defined as the area drained by a given river or by a river system (CHRISTOFOLETTI, 1980).

The area is located on 18 distinct micro-basis with small and medium dimensions which drain directly to the Camaquã River and to the secondary drains of the basin (the Passo do Meio stream and the Sapata stream).

The watershed of the Camaquã River is classified as rivers that present drainage directly to the sea, when the drainage of its waters is made continuously to the sea or ocean, that is, directly into the sea level, as defined by Christofoletti (1980), and the exuvial of the basin on the right bank of the Patos Lagoon.

The study region represents only a small fragment inserted entirely in the catchment area of the Camaquã River and presents a hydrological labyrinth composed by micro-basins and streams of smaller hydrological capacity of drainage and of small proportion, the small streams (the water mesh can be observed in Figure 06).

According to Oliveira (1980, p.502), small streams corresponds to an intermittent stream in the southern region of Brazil. In the IBGE (2010, p.29) conceptualization, "sanga" means small stream that dries easily, a small stream of water, in general, a water drain used in Rio Grande do Sul State. 
Regarding the classification, based on the consistency of flow, Oliveira (1980) and IBGE (2010), conceptualize the small streams with intermittent behavior, although in practice this behavior may not be a rule. When water courses were observed during the period of the research, the flow behavior of these rivers is in the perennial classification. According to Villela and Mattos (1975, p.12), these watercourses contain water at all times, the underground sheet maintains a continuous feed and never descends below the bed of the watercourse, even during the most severe droughts.

Christofoletti (1980) classified the watercourses in a genetic way, considering them in relation to the slope of the geological layers. Analyzing the drainage network for the delimited research fragment, we observed the establishment of a network called insequent rivers, and these courses are established when there is no apparent reason to follow a pre-established general orientation, that is, when no control of the geological structure becomes visible in the spatial arrangement of the drainage. The bodies of water flow according to the particularities of the morphology, in varied directions. They are common in areas where the topography is flat and in areas of lithological homogeneity like in the granitic or igneous areas, as was shown the lithology in the study area.

The classification of the small streams based on the morphology of the channels for the study area, occurs in relation to the morphometric parameters. In this way, we delimit the channels as being rectilinear, morphologically described as single channels with longitudinal bars.

The analysis of the drainage patterns refers to the spatial arrangement of the fluvial courses, which can be influenced in their morphogenetic activity by the nature and arrangement of the rock beds, by the different lithological resistances, by the differentiations in the slope of the terrain and by the transformation of the geomorphology of the region (CHRISTOFOLETTI, 1980, p.103).

Regarding the fundamental types of drainage patterns and their occurrences for the study region, they can be classified, according to Christofoletti (1980):

- Dendritic drainage: Also referred to as arborescent, since its development resembles the structure of a tree, where the channel of the main stream characterizes 
the trunk and the tributaries configure the branches and these are dispersed in all directions of the surface of the land. This pattern develops on rocks of uniform resistance like the granite complex. And the rivers that constitute this pattern form confluences at acute angles of varied gradations, with rare confluences at right angles to this pattern and, when they occur, are due to tectonic anomalies (faults, joints or diachras).

The river hierarchy refers to the order of the water courses, corresponding to the degree of bifurcation and branching between the channels within the basins, for the geographic clipping used in the micro-basins analyzed. The determination of the order of the rivers, besides indicating their degree of branching, helps in the morphological analysis of the watershed (BACK, 2014, p.74).

The criterion for classification was proposed by Horton in 1945 (HORTON, 1945) and modified by Strahler (1957). According to the classification proposed by Strahler, this one eliminated the subjectivity of the Horton criterion that started from the designation of the main river from the nascent to the exudory with the same order number, among other peculiarities that the method of Horton had adopted.

Figure 06 - Drainage network of the study area

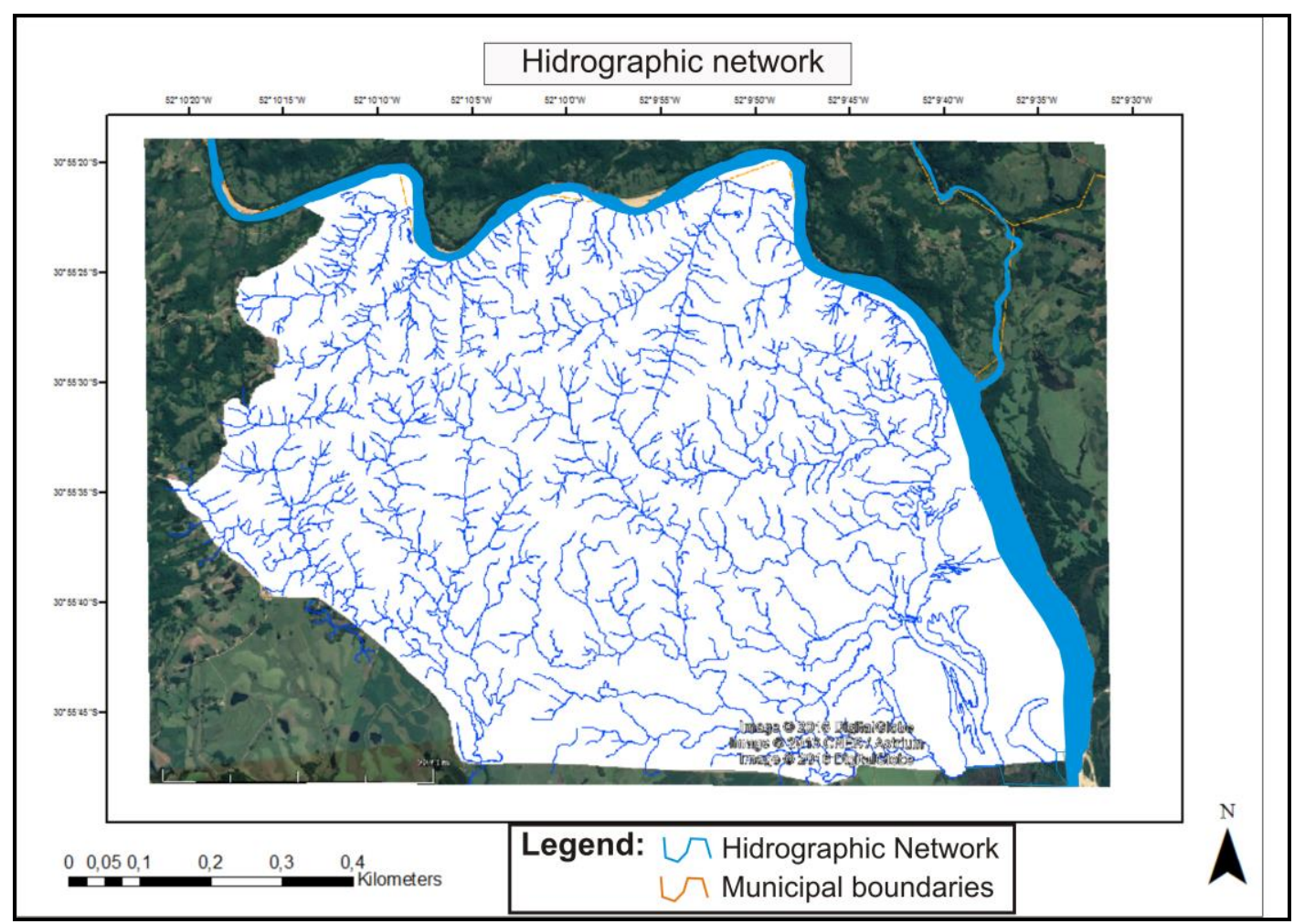


For Strahler (1957), the criterion could be explicitly simpler, in which the smaller and unbranched tributaries are classified in the first order and the union of channels of the same order (i) form a channel of order $(i+1)$. When different order channels come together, the subsequent channel remains with the larger of these two orders. Strahler's proposal eliminates the concept that the main river should have the same order number in its entirety and the necessity of re-numbering at each junction of a new tributary.

The physical characterization of hydrographic basins refers to, among other characteristics, the size, shape and slope that influence the hydrological behavior of these hydrographic basins. The flow volume, peak flow and water outflow velocity of the basin and the flow time and sediment transport are directly related to the physical characteristics of the basin.

Even though the studied watersheds are in a context of anthropization and a strong alteration in the landscape, contributing to the sediment load by the activities developed there, these variables were not analyzed in this study.

\subsection{Biogeography}

The biogeography of the region is considered to be diversified, phytogeographically presented as a transition environment, with plant species of Submontane Semidecidual Seasonal Forest in the southeastern mountain range and the Alluvial Semi-deciduous Seasonal Forest, commonly known as gallery forest, or riverine forest, in the lower part, flat and prone to flooding during flood periods of the river.

According to Schimper (1898), who was an exponent of phytogeography, there are two large groups of plant formations: climatic and edaphic. It can be said that the proper formation of Rio Grande do Sul is a Subtropical forest of climatic order; variations are due to the soil; the systematic composition is a result of the temperature (RAMBO, 2015).

Still according to the plant formations of the study area in the low-end portion, along with (WAECHTER and JARENKOW, 1998), considering the pedological, 
geomorphological and climatic conditions, it has a lower floristic richness compared to the northern regions of the Coastal Plain itself and other areas in the state.

With the soil saturated most of the time, conditioned to floods by the geomorphological conditions, by the periodic floods that also collaborate for a reduction in the floristic diversity, selecting and restricting the species that can occupy the riverside environment (BERTANI et al., 2001), by the environmental dynamics provided by the interaction of the soil with the river, there is a dynamic of environments and a heterogeneity that favors the implantation of select species (MANTOVANI, 1989).

For the slopes of the southeastern mountain range, the vegetation cover has a forested structure, being directly linked to soil conditions, conditioned by the weathering of the granite, and thus the same is responsible for the formation of the natural landscape of the Southeast Mountain Range (RAMBO, 2015). Many laterite areas appear and this, unlike clay, does not offer necessary materials to the plants, a phenomenon that is the explanation for the occurrence of the vegetation of the Southeastern Mountain Range being scarce and creeping on laterite surfaces (RAMBO, 2015).

Another important determinant, for the primary forest sites is that they do not have expressive docile on the slopes and high topography areas and there exists high abundance of rocky outcrops found on the slopes of this region, provided by physical weathering (JURINITZ and JARENKOW, 2003).

According to (KER et al., 1986), they are from shallow to deep soils characterized by the presence of a reddish-yellow textural B horizon. Complementing the classification, Tomé Júnior (1997) classifies this soil as having a medium texture with low to moderate susceptibility to erosion, presenting average levels of organic matter and very low $\mathrm{pH}$.

\subsection{Fauna}

The flat area environment results in a great wealth of species since it offers a great variety of habitats for the vegetation and, as a consequence, offers places of 
shelter, reproduction and feeding for the fauna. In this environment, there is the broad-snouted caiman (Caiman latirostris), winter concentrations of Anatidae (mallards and swans) and Rallidae (Fulica spp. and Gallinula chloropus, woodcocks).

\subsection{Flora}

Some Araucaria enclaves were recorded on the slopes of the Caçapava do Sul massifs (AB'SABER, 2003, p.22). Still according to Behling et al. (2016), by means of palynological studies, the same possibility was verified. Thus, it was found as punctual occurrences cactaceae, apparent relics of a drier paleoclimate of the Upper Pleistocene.

This system, which is not unlike the rest of the environment, has been losing its natural characteristics due to the changes caused by anthropic occupation, such as drainage of floodplains and plains for irrigation and cutting of the forest and owing to agricultural or pastoral use. The removal of herbaceous and shrubby vegetation from the banks of the Camaquã River and its riparian environments provoke strong erosion of the banks, with the fall of the ravines, resulting in an expressive loss of portions of the forested land which results in visible siltation (BORGES-MARTINS, 2007).

The riparian vegetation that marginalized the "sangas" was extremely devastated, determining slight nesting ravines and a strong acceleration of fluvial erosion (AB'SABER, 2003, p.22).

According to an analysis by Rambo (2015), the mountainous part presents a natural and anthropogenic stratification that can be classified as forest (from shrub vegetation to tropical forest) and meadow (steppe, prairie and field).

Also along with Rambo (2015), this part of the territory can be divided into four distinct formations. From this total, it was possible to group some sets, considering the characteristics of the vegetation resulting in four groups: Fields (clean and dirty); Barns (regenerating forest, primary stage); Regenerating forest (secondary stage); Adult forests (developed stage that includes isolated capons and gallery forest). The arboreal composition of the study region can be observed in figure 07 and it was described below: 
a) Clean field: interspersed with many granite blocks discovered or semi-buried with vegetation of grasses and composts, being no more than half a meter high. Dirty field: covered with carquejas (Baccharis), bushes of tall grass. It develops in very flat areas or where the soil has deeper profiles. It can be found species like Palm (Opuntia monacantha), the tuna (Cereus peruvianus) and grass of the species Andropogon and Baccharis psiadioides.

There are many points with granite outcrops in large blocks of tens of meters of height and that concentrate a specific vegetation of environment without pedological cover such as lithophytes, round cacti in the shape of a hedgehog (Echinocactus), columnar tunas (Cereus), gravy (Dyckia) and an infinity of crusty and foliaceous lichens;

b) Brooms: formed of shrubs of up to 03 meters high which consists most of the red-broom (Dodonaea viscosa) and the bush species of common brooms (Baccharis) are mixed with the dirty field. At this stage are common: common broom (Baccharis dracunculifolia), wild tobacco (Solanum mauritianum) and several species of Eryngium. Shrub or subarborescent mats with the greatest significance for the hard and contorted shrubs of the myrtaceous family, spittle sarsaparilla weeds (Smilax); bignoniaceous and others; This formation constitutes the upper limit of the closed jungle vegetation, butis (Butia capitata);

c) Arborescent or tall bush containing (Fagara), Chalchal (Allophylus edulis), horse whipping (Luhea divaricatar), coconuts (Erythroxilum), cinnamons (Nectandra), black heart (Maytenus cassineformis), willow (Salix humboldtiana), baillon (Sebastiania commersoniana), vegetation of vines with species belonging to the bignoniaceae, liliaceae, malpighiaceae and passifloraceae families; the tallest trees are covered with epiphytes, woody beards (Tillandsia usneodis), orchids, ferns and piperaceae.

Bushes formed by specimens of common acrylate (Lithraea brasiliensis), aroeira parsley (Schinus molle), capororoca (Myrsine umbellata), tea bugre (Casearia sylvestris), red cambodia (Cupania vernalis Cambess), howler monkey (Dalbergia 
frutescens) and grandiuva (Trema micranta) which is quite common in all environments.

d)Capons, clearly detached from the forest with a closed structure are located along the springs on the slope. Among some of its specimens, it can be mentioned Guabira (Campomanesia xanthocarpa), Jerivá (Syagrus romanzoffiana) and Machaerium stipitatum.

A gallery forest which accompanies the watercourse starting sub-shrubs at the sources, developing into little nurseries on the dry and rocky slopes, and ending in regular range forests, diversifying according to the volume of water and alluvium.

Virgin woodland that resembles the subtropical forests of the plateau regarding the composition. It is along the Camaquã River, as well as in the more voluminous arms, with vegetal species that reach large size like Timbauva (Enterolobium contortisiliquum), Laurel (Cordia trichotoma), Canjerana (Cabralea canjerana), Cedrella (Cedrella fissilis), Canjerana (Cabralea canjerana), Ipe (Tabebuia chrysotricha), Angico vermelho (Parapiptadenia rigida) and Pinheiro-bravo (Podocarpus lambertii).

In the flattest area, which is composed of fields with natural characteristics, it corresponds to the largest area for this sector, in a smaller plot. It also presents a naturally sedimentary environment with swamps, lagoons, beach deposits and abandoned meanders.

In swampy environments, marshy vegetation presents floating types with no terrestrial roots, such as the Aguapes (Eichhornia crassipes) with beautiful blue inflorescences (Salvinia auriculata and Azolla filiculoides) and species like Wolffiella and Lemna as well as families such as Lemnaceae and Pontederiaceae; species of submerged rhizome and leaves extended in the air like Leather Hat (Echinodorus grandiflorus), other species found in the loamy margin such as Heteranthera and various grasses, Hydrocotyle, the sorrel of the species Oxalis.

In the parts where the fields prevail, the vegetation finds a hard and dry soil. In the field areas, the vegetation cover was thin and low formed in its great mass of grasses and cyperaceae. The common grasses of the Rio Grande fields, such as 
Andropogon leucostachyus, Cenchrus tribuloides, Paspalum, Fimbristylis complanata, Kyllinga pungens, Hydrocotyle umbellate and Centella asiatica coexist in concomitance with Hyptis labiadas, Solanum sisymbriifolium, Eryngium nudicaule, Macrosiphonia longiflora, the Pampas grass (Cortaderia selloana), a good number of species of Panicum, Paspalum, Eriathus, Andropogon, Baccharis (Carqueja), certain grasses of the genus Erianthus, Elionurus e Anana (Ananas bracteatus) as well as pteridophytes of the genus Pteris, Gleichenia and Lycopodium.

Many grasses, such as cyperaceae, iridaceous, leguminous, umbelliferous and the small Aristolochia sessilifolia, the leaves are reduced to rudiments as in many verbenaceae of the genera Verbena and Lippia and there is also the common broom Baccharis dracunculifolia with strong aromatic smell.

On the wet banks of the lagoons and in the forest areas on dry land species such as (Erythrina cristagalli) that always line the waterways, the willow by the edge of the water (Salix humboldtiana), the Sarandi on the edge of the river (Sebastiia schottiana), Terminalia australis, Ficus cestrifolia, Syagrus romanzoffiana, Bromelia fastuosa, Cedrela fissilis, Gleditschia amorphoides, Yellow araça (Psidium cattleyanum), angico (Parapiptadenia rigida), claw of the cat ( Acacia bonariensis), camomile (Myrciaria tenella) and other species of Myrtaceae such as bronquilho (Sebastiania commersoniana), bull shade (Acanthosyris spinescens), aroeira brava (Lithraea brasiliensis), representing vines and lianas (Bignonia sciuripabula) besides the straight and white curls of Escallonia bifida.

Most of the typically country plants have closely united inflorescences, chaplets and condensed ears. This arrangement has a dual purpose: first, by the intimate union of flowers, the effects of the sun are reduced; second, by the cluster of many small and minimal flowers, they result in showy inflorescences, easily identified by pollinating insects (RAMBO, 2015). 
Figure 07 - Vegetable composition of study

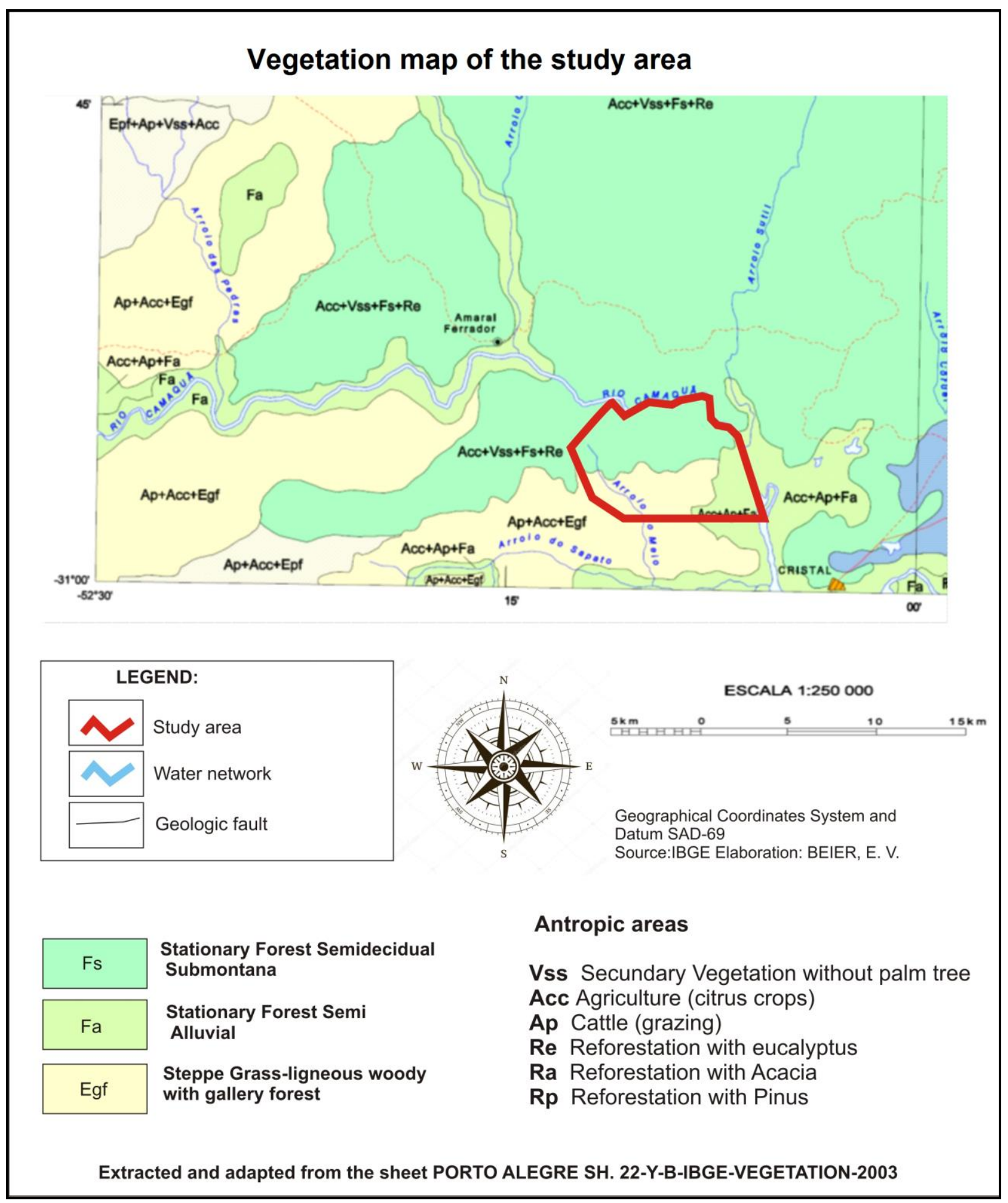

Source: Adapted from IBGE (2003)

Currently, the number of portions of the territory converted to silviculture, bracatinga (Mimosa scabrella, eucalyptus, various species) is increasing; black acacia (Acacia mearnsii) and pinus (Pinus elliottii). These last three, by their ease of natural dispersion become invasive, affecting naturaland and regeneration areas. 


\section{Final considerations}

The study proposed the environmental characterization of the delimited area, considering different environmental components. This investigation was considered analyzing the disposition of the natural elements in the landscape and its delimitation in the space.

It is concluded with this analysis that the natural characterization of the region has a close connection with the variables that shape and transform it such as climate, geology and pedology resulting in a specific phytogeographic classification adapted and a water network imposed by the climate and by geology resulting in rivers always fed hydrically.

It was also observed a diverse flora and fauna conditioned by geological, geomorphological and climatic formation resulting in a diversified and dynamic environment with overlapping species of two distinct environments.

Environmentally, the characterization of the region is altered by anthropogenic actions revolving the soil, rectifying the water network and predating the native flora and fauna for the imposition of specimens and activity that require management and mechanization.

\section{Acknowledgment}

The Capes, for incentive research, to the reviewers contributing to suggestions and improvements.

\section{References}

AB 'SABER AN. The domains of nature in Brazil: Brazilian landscape potential. Ateliê Editorial: São Paulo; 2003

BACK AJ. 2014. Hydrographic basins: Classification and physical characterization (with HidroBacias program for calculations). Florianopolis, Epagri. 162p. 
BRAZIL. Ministry of Agriculture, National Department of Agricultural Research, Division of Pedological Research. Survey of Soil Recognition of the Rio Grande do Sul State. Rio de Janeiro, p. 431, 1973.

BEHLING $\mathrm{H}$ et al, Late Holocene Vegetation History and Early Evidence of Araucaria Angustifolia in Caçapava Do Sul in the Lowland Region of Rio Grande Do Sul State, Southern Brazil. [cited 2018 fev 12]; Braz. arch. biol. technol. vol. 59. Curitiba: 2016, Epub, Apr 29. Available from: http://www.scielo.br/pdf/babt/v59/1516-8913-babt16150264.pdf.

BERTANI DF, Rodrigues RR, Batista JLF, Shepherd, GJ. 2001. Temporal analysis of floristic and structural heterogeneity in a riverine forest. [cited 2018 fev 20] Brazilian Journal of Botany, v. 24, n. 1, p. 11-23. Available from: http://www.scielo.br/scielo.php?script=sci_arttext\&pid=S0100-4042001000100002

BITENCOURT ALV. Paleoambiental Reconstitution of the Banhado do Colégio Region, Camaquã, RS. [dissertation]. Porto Alegre, UFRGS; 1992.

BORGES-MARTINS M, ALVES MLM, ARAUJO ML DE, OLIVEIRA RB DE AND ANÉS AC. Important areas for conservation in the Coastal Plain of Rio Grande do Sul. In: BECKER, F.G .; R.A. RAMOS and L.A. MOURA (orgs.) Biodiversity: Regions of the Lagoa do Casamento and the Butiazais de Tapes, Coastal Plain of Rio Grande do Sul. Ministry of the Environment, Brasília. 2007, 385 p.

CHRISTOFOLETTI A. Geomorphology. São Paulo: Edgard Blücher. 1980.

EMBRAPA. Manual of soil analysis methods / National Soil Research Center. - 2. ed. rev. current. - Rio de Janeiro, 212p .: il. (EMBRAPA-CNPS. Documents; 1). 1997.

HOFMAN JL. Vertical Movement of Artifacts in Alluvial and Stratified Deposits. Current Anthropology, [cited 2018 jan 12]. Vol. 27, No. 2, pp. 163-171, Apr. 1986.

HORTON RE. Erosional development of streams and their drainage basins: hydrophysical approach to quantitative morphology. Bulletin of the Geological Society of America. 1945, 56, 2 75-3 70.

IBGE. Sheet SH.22-Y-B. Porto Alegre: Geology, 2003.

IBGE. Sheet SH.22-Y-B. Porto Alegre: Vegetation, 2003.

IBGE. Sheet SH.22-Y-B. Porto Alegre: Geomorphology, 2003.

IBGE, Brazilian Institute of Geography and Statistics. Statistics on Education and Work, Sense of 2010. [cited 2017 feb 27]. Available from: https://cidades.ibge.gov.br/ 
JURINITZ CF, JARENKOW JA. The Structure of the Arboreal Component of a Seasonal Forest in the Serra do Sudeste, Rio Grande do Sul, Brazil. Journal of Botany, São Paulo, 2003. [cited 2017 dez 12]; n. 4, p. 475-487. http://www.educadores.diaadia.pr.gov.br/arquivos/File/2010/veiculos_de_comunicaca o/RBB/VOL26N4/20689.PDF

KELLY RL. Mobility/Sedentism: Concepts, Archaeological Measures, and Effects. Annual Review of Anthropology. 1992, Vol. 21, pp. 43-66.

KER JC, Almeida JA, Fasolo PJ and Hochmüller DP. Pedology - exploratory survey of soils. In Survey of natural resources. Brazilian Institute of Geography and Statistics, Rio de Janeiro. 1986, v.33, p.405-540.

KÖPPEN W. Das geographisca System der Klimate. In: KÖPPEN, W.; GEIGER, G. Handbuch der Klimatologie. C. Gebr, Borntraeger, Berlin. 1936, p. 1-44.

MANTOVANI W. Conceptualization and conditioning factors. In: SYMPOSIUM ON MATA CILIAR, 1989; 1998, Campinas, Brazil, São Paulo, 1998.

OLIVEIRA C de. . Cartographic Dictionary. Rio de Janeiro: IBGE. 1980; 447 p.

PEREIRA JG. 2011. Contribution to the geological study of the Caquaquã-RS Basin through 2.5D aeromagnetic modeling. Dissertation. Porto Alegre: Departament of Geociences/UFRGS; 2011. 142p.

PROUS A. Lithic artifacts: descriptive elements. Archives of the Museum of Natural History, Belo Horizonte. 1986/1990; v. 11, n. 1, p. 1-88.

RAMBO BSJ. The physiognomy of Rio Grande do Sul. $4^{\text {th }}$ revised edition. São Leopoldo: Ed. Unisinos; 2015 p.398.

RIO GRANDE DO SUL. SECRETARY OF THE ENVIRONMENT OF RIO GRANDE DO SUL. Wind Atlas. SEINFRA; 2002.

ROISENBERG A, MARQUES JC, BACHI FA, FRANTZ JC. Gravataí- SH.22-X-C-V, scale 1: 100,000: Explanatory note. 72p. Geological map, Rio Grande do Sul: UFRGS/CPRM; 2007.

ROSSATO, MS. The climates of Rio Grande do Sul: variability, trends and typology. PhD thesis. Porto Alegre: Institute of Geosciences/UFRGS; 2011. 253 p.

SCHIMPER AFW. 1960. Plant geography: upon a physiological basis. New York: Hafner. 839 p. Reprinted -original de 1898. 
TECHNICAL SERVICES OF ENGINEERING S.A. (STESA). Elaboration of EIA / RIMA and PBA for the Environmental Licensing related to the Adequacy of Capacity and Duplication of the Highway BR-116/RS; 2010.

STRAHLER AN. Quantitative analysis of watershed geomorphology. New Halen: Transactions: American Geophysical Union. 1957; v.38. p. 913-920.

TOMAZELLI LJ AND VILLWOCK JA. The Cenozoic in Rio Grande do Sul: geology of the Coastal Plain. In: Holz, M. and De Ros, L. F. eds. Geology of Rio Grande do Sul. Porto Alegre, CIGO/UFRGS, Edition. . 2000; p. 375-406.

TOMÉ JÚNIOR JB. Manual for interpretation of soil analysis. Farming Publishing Company Library, Guaíba; 1997.

VILLELA SM AND MATTOS A. Applied hydrology. São Paulo, McGraw-Hill; 1975, 245p.

VILLWOCK JA, TOMAZELLI LJ. Coastal geology of Rio Grande do Sul. Technical Notes. Center for Coastal and Oceanic Geology Studies. Porto Alegre: UFRGS, 8, 1995, p.1-45.

VILLWOCK JA, TOMAZELLI LJ, Loss EL, Dehnhardt EA, Horn, F'NO, Bachi FA and Dehnhardt BA. Costal geology of the Rio Grande do Sul in: Rabassa, j. (ed.). Quaternary of South America and Antartic Pensinsula. A.A. Balkema, Rotterdam; 1986, 4:79-97.

WAECHTER JL, JARENKOW JA. Composition and structure of the arboreal component of Taim, Rio Grande do Sul. Biothemes. 1998; v. 11, n. 1, p. 45-69. 